\title{
LAMENT OVER LONDONGRAD: REFLECTIONS UPON THE FOOTSTEPS OF MILOŠ CRNJANSKI
}

\begin{abstract}
In 1946, Miloš Crnjanski started writing a novel in English entitled The Shoemakers of London. Against the harsh realities of both his exile in Britain and of his English functional but unequal to the exigencies of writing fiction - the work remained unfinished only to be transformed into A Novel of London (1971), one of the masterpieces of Serbian literature. Both my life and my writing are, to some extent, following in Crnjanski's footsteps. I could not but be aware of small triumphs in the very places where he failed, whether it be the fact that I hold a professorship at Exeter University, where he had hoped to get a teaching job but never did; or that, in 2015 and in 2018, my own novels of London briefly occupied the Piccadilly shopfront of Hatchards, the bookshop for which he worked as a deliveryman. Such successes only highlight my sense of humility before his writing. It would be a folie de grandeur even to begin to compare our literary achievement, but I will dare to use our examples in order to contemplate the changing notions of being a Serbian writer in the United Kingdom.
\end{abstract}

Key words: Miloš Crnjanski, A Novel of London, Vesna Goldsworthy, Monsieur Ka

"It is harder to write in English than to speak it. I can now see that it would have taken me at least twenty years to become English", (Crnjanski 1992: 36, trans. by G. Snel)

In 1946 Miloš Crnjanski began writing a novel in English entitled The Shoemakers of London. It was inspired by a period of employment as a book keeper in a Bond Street shoe shop, one of a series of menial, short-lived jobs that contributed to the patchwork émigré CV of this Serbian writer who had, before the war, enjoyed both a well established diplomatic career and a reputation as one of Yugoslavia's leading poets and novelists. ${ }^{1}$ The hardships of exile in the British capital, where he

\footnotetext{
*Department of English, University of Exeter, Queen's Building, Queen's Drive, Exeter EX4 4QH; e-mail: V.Goldsworthy@exeter.ac.uk

${ }^{1}$ The basic facts of Miloš Crnjanski's life will be well known to the readers from the former Yugoslavia, but it is worth repeating them here, because, although he is one of the key figures in the history of Serbian
} 
arrived from a posting in Rome, via Portugal, in August 1941, and the deficiencies of his English - functional but unequal to writing fiction - conspired to leave The Shoemakers unfinished. The proposal failed to elicit interest among British publishers in spite of efforts by eminent friends and supporters, among them the novelist Rebecca West.

Many years later, by now again living in Belgrade, Crnjanski returned to the story in his Serbian mother tongue and transformed it into A Novel of London (1971). This two-volume work was recognised almost immediately as one of the masterpieces of twentieth-century Serbian and Yugoslav literature. In spite of the novel's originality and its intricately evoked London setting, its seven hundred pages remained in their turn untranslated into English for another half a century, during which time its translations into a number of major European languages achieved acclaim. A translation by Will Firth, funded by the Serbian Ministry of Culture, is now scheduled for publication by Dialogos, a small, New Orleans based, publisher, early in 2020.

Until that translation appears, and probably even afterwards - given that English translations from small languages count as successful if they reach a couple of hundred people - A Novel of London will continue to represent a curious spectral presence for a Serbian writer writing in English such as me. Crnjanski is a ghost I may be in conversation with, but whom the vast majority of my readers never get to see. At the same time, and for that tiny minority of them who also happen to be Serbian speakers, A Novel remains an inevitable point of reference and comparison, as though each Serbian book about London must on some level be a response to his work.

In my case, Crnjanski is undoubtedly a major influence. I have read $A$ Novel of London four times. First, as a teenager in the seventies, when I loved his distinctive lyrical voice but found his story of the Russian émigré couple struggling to make ends meet in Mill Hill both too long and too depressing. Although I hadn't yet at that stage visited London, Crnjanski's snow-bound, inhospitable city emerging from the ruins of the Blitz had little in common with the London of my imagination. In spite of newspaper reports of a three-day week and power cuts which the state-controlled Yugoslav press

literature, he is practically unknown outside specialist circles in the English-speaking world. Crnjanski was born in 1893, to a Serbian family living in Csongrad, in what was then Austria-Hungary (now in Hungary), and he was educated in Pančevo (now in Serbia), Timişoara (now in Romania), Rijeka (now in Croatia), and Vienna, where his studies were interrupted by the First World War. He was drafted into the Austro-Hungarian army (which was then fighting Serbia) and he fought against the Russians in Galicia (now in Poland). After the war, he completed his studies in literature at the University of Belgrade in 1922, and worked initially as a school teacher and later as a journalist. He joined the Yugoslav diplomatic service in the 1930s (another diplomat was the future Nobel literature laureate Ivo Andrić). Postings in Germany and Italy were followed by evacuation to Britain after the fall of Yugoslavia to the Axis powers in 1941, and a carefully negotiated return to Belgrade in 1965. He died in the Yugoslav capital in 1977, at the age of 84. 
carried at this time with more than a degree of Schadenfreude, my teenage London was cool only in a metaphorical sense: the city's soundtrack was provided by Led Zeppelin, Deep Purple and the Rolling Stones as much as by Crnjanski. It is telling of former Yugoslavia as much as of me personally, that I received a copy of A Novel of London and Pink Floyd's album The Dark Side of the Moon in the same bundle of precocious gifts from friends for my fourteenth birthday in 1975.

I read Crnjanski's novel for the second time as a student of literature at Belgrade University in the early 1980s. This time round, I was more receptive both to its detailed depictions of a bleakly austere London and its romantic idealisation of married love, and more appreciative of its polyphonic literary orchestration. Indeed, had anyone asked me to name my favourite writer at this stage, I would not have hesitated to name Crnjanski.

My third reading of $A$ Novel took place in the early nineties. I was by this time living in London and researching British representations of the Balkans for my book Inventing Ruritania: The Imperialism of the Imagination (1998). Crnjanski's biting portraits of the English offered a useful counterpoint to the condescension with which so many British writers of his era wrote about the Balkans. The lack of understanding was mutual, even if only one side in that particular cultural exchange had the luxury of not needing to care.

I read $A$ Novel for the fourth time after I finished editing the final draft of Monsieur Ka (2018), my own novel about Russian exiles in London, based on the imagined life of Sergei, Anna Karenina's son. Monsieur Ka is set in 1947, only a fraction later than Crnjanski's work, but in a different part of the city and among a very different community. My main characters are a cosmopolitan cast which includes the French, the English, the Germans and the Hungarians, as well as the Russians. I spent many hours on the web and in the archives researching period detail - political and social events, weather reports, secular and religious calendars, street maps, concert schedules, film listings, restaurant menus, and railway timetables. I tried, sometimes to the point of obsessiveness, to be as exact as possible in my reconstruction of postwar London. If it rains, or if there is a piece of music on the BBC while Albertine, my French narrator, sews a dress or reads a specific issue of a magazine, it is because it was really raining on that particular day, the piece was really playing on the radio, and the magazine had just appeared.

I read or reread many British writers of the 1940s for the flavour of their language and setting as I worked on the drafts of Monsieur Ka, but I held back on Crnjanski. I admit, I feared that his distinctive, incantatory and melancholy Serbian rhythms would not leave my ear and that their echoes would not help my English, already stretched to its limits by the challenges of writing in a historic idiom. 
Remembered scenes from his novel did, nonetheless, float to mind as I wrote. Rather than trying to ignore them, I often researched them further and I responded to a few. In a perceptive analysis of Monsieur $\mathrm{Ka}$ in the Los Angeles Review of Books, the Russian-American novelist Lara Vapnyar writes the following about the novel's intertextual connections with Tolstoy:

If that outline doesn't strike you as the most delightful literary tangle, Goldsworthy presents the true lovers of Tolstoy's novel with another one: a scavenger hunt for references to Anna Karenina. The clues are sprinkled throughout Monsieur Ka with such care that finding yet another reference never fails to be rewarding. (Vapnyar 2018)

The readers of Crnjanski could follow a similar, albeit more discreet, trail through my novel. For example, I spent a long time tracking down the advertisement for Emu wool ("Stop thinking about shrinking") that Crnjanski mentions en passant in A Novel, and I placed it on the side of a London double-decker bus, while in the window just above it, I positioned a passenger who looks exactly like his hero, Prince Repnin. Similarly, I established the dates and the movie theatres where Pathé News showed clips of the victory parade in Moscow ahead of the main feature in 1947, in order to have my exiled Russian family credibly confront the same sight of marching Soviet troops as Repnin did so memorably in Crnjanski's novel. It is a commonplace in accounts of political exile a reckoning with the images of the place to which you cannot return - but few writers evoke the torment and the ambivalence as powerfully as Crnjanski does.

"I was writing The Shoemakers in the London suburb of Finchley in 1946-47", Crnjanski recollected in an interview, "while I was, with my wife, very close to suicide [...] my life had written that book." (Bunjac 1982: 86, my translation) Perhaps because Crnjanski's alter ego, Prince Repnin - melancholic, increasingly depressed and finally suicidal - features so strongly in the Serbian imagination, my Sergei Karenin could appear to be an exercise in contrasts, offering black humour where $A$ Novel would have offered only darkness. My Russian characters react to their enforced exile in a variety of ways. Some are failures, others succeed better than the locals. Some are homesick, others hate their homeland. Some try hard to remain Russian, others are just as keen to assimilate and become English. Crucially, the narrative of their exile is refracted through the eyes of Albertine, my French narrator, who rejects the very concept of nationality and homeland: she feels she no longer has either. Europe as a whole seems tainted by the war. In a sense, the most homesick of them all is Albert, my central English character. He longs for the lost India of his childhood more than the Karenins yearn for the tsarist Russia. 
Crnjanski is both a virtuoso of lyricism and a master of the epic sweep, but he is never a funny writer. In contrast, Sergei Karenin has something I perceive as a deliberately Nabokovian quality: a somewhat forced jolliness, the feeling of a duty to cheer people up, an inclination to punning borne out of multilingualism, a certain childishness, and even that slight preciousness which irritates the detractors of Nabokov. Next to Crnjanski, Nabokov, both as a person and as a writer, seems a slightly incongruous influence, because their voices are so different. Compared to his own struggles, Crnjanski might have said that Nabokov had led a charmed life. He was six years older than Nabokov, and they died in 1977, within four months of each other. I am not sure if their paths in exile ever crossed, but I suspect that they would not have got on.

Because Crnjanski was such a formative early presence in my reading life, I am more aware of walking in his footsteps, and - in the Bloomian sense - more anxious about his influence than I am about Nabokov or any number of other writers in English or Russian. The awareness that I am following in Crnjanski's trail extends to my personal life too, often with a comic touch. In my memoir, Chernobyl Strawberries (2005) I write about my move to London in the mid-1980s. It took place against the backdrop of my wider family's Anglophobia (a feeling that Crnjanski both shared and contributed to), and understandable worries about the hardships that must lie ahead for me. Because the facts of Crnjanski's life are so well known in Serbia, they were often used to articulate anxieties about my future, as though Britain was still the same inhospitable place it was in the 1940s. If a person of Crnjanski's stature could not get a teaching post anywhere in the UK, nor indeed any, even semi-decent, graduate employment, in spite of going so far as to take extramural courses at the University of London, if he could only get work as a book keeper or a manual labourer, what hope was there for me?

While it would be hubristic to draw too many comparisons between us, I heard such questions so often that I could not but register occasional small triumphs in the very places where he failed, whether it be the fact that I now hold a professorship at Exeter University, where he had hoped but never succeeded to get a teaching job while it was still a University College; or that my own novels of London - Gorsky (2015) and Monsieur Ka (2018) - briefly occupied the Piccadilly shopfront of Hatchards, the bookshop for which he had worked as a delivery man.

There is one further geographical point of connection. I spent fifteen years teaching at Kingston University, not far from Kingston Hill, where Crnjanski lived in a house lent to him by Lady Leila Paget, whose generosity towards Serbia and the Serbs is well documented. In Chernobyl Strawberries, I described the arrangement in the following way: 
In the forties, in a room in the coach house which stood in the Japanese Garden of Warren House, the Kingston Hill residence of Lady Paget, the Serbian novelist Milos Tsernianski wrote the second volume of Migrations, a haunting story of exile and loss, one of the greatest Slavonic books. The Tsernianskis could not afford to pay rent, and repaid their benefactress in kind. Milos, a former Yugoslav diplomat, used his calligraphic skills to address her party invitations and his wife, Vida, baked biscuits for Lady Paget's guests. It is terribly unfair, but I keep thinking of the couple as pets, a pair of Pekinese perhaps. I imagine Lady Paget turning towards one of her friends and saying, against the clinking of porcelain cups, 'I keep a Serbian novelist here, you know, my dear.' To his credit, Tsernianski was never a particularly grateful guest: indeed, the veiled references to his hostess in his novels are invariably ironical and bitter. He was a pet Piranha rather than a pet Pekinese, biting the hand that fed him. ${ }^{2}$ (Goldsworthy 2015: 160)

When the memoir appeared, I received letters from the descendants of the Serbian wartime émigré community explaining the context of Crnjanski's residence in Kingston and putting me to rights about Crnjanski's difficult character and Leila Paget's generosity. The dwelling Crnjanski described as stable for horses ("konjušarnica") was in fact, my correspondents claimed, a perfectly comfortable mews house in a beautiful garden. Many of their parents, also freshly escaped from Yugoslavia, would have been more than happy in such a place. Not only did Leila Paget not expect Crnjanski and his wife Vida to contribute to their rent by working as I had wrongly deduced from the many complaints he had expressed in his diaries and his correspondence, but she had invented those jobs in order further to help them financially, sparing their dignity by avoiding straight handouts. Poor Madame Vida knew this well, the letters said, and she was devastated when the couple had to move from Kingston Hill because of Crnjanski's difficult temper. Their subsequent lodgings in Queensway were vastly inferior.

While the letters I received do not dispute Crnjanski's literary greatness, the character reference emerging from them is not exactly flattering. They made me readier to see things from Leila Paget's point of view. Crnjanski's habit of describing her, and most women his own age and older as "babe" (lit. 'grandmothers' / fig. 'crones'), did not exactly encourage sympathy. The poet whose lyrical verse made you envy the women who were his inspiration was also a man whose attitudes made you pity those same women. "I find the thought of returning to Belgrade terrible after so many years",

\footnotetext{
${ }^{2}$ I use anglicised spelling of Crnjanski's name in this book.
} 
he said in 1965 to the then Yugoslav ambassador to London Srdjan Prica; "The saddest thing is that I would get to see all those once beautiful women, now crones [babe]." (Popović 2008, my translation) Even allowing for the brittleness of an elderly man who had once enjoyed a reputation as a heartbreaker, this was not a pretty sentiment to express. I had to break with the emerging convention of our times and learn to love the writing while ignoring the man.

$* * *$

When I moved to London I also moved away from the study of Yugoslav and comparative literature to the study and then teaching of English literature and latterly creative writing. The shift has made me more alert to the English influences in Crnjanski's work. The context of English literature - with which he was surrounded, sometimes literally so, as in the case of his work at Hatchards, and to which he responded in a number of his own commentaries on writers ranging from Geoffrey Chaucer to Philip Larkin - is an underexamined aspect of Crnjanski's work, most particularly A Novel of London but also The Lament over Belgrade and some of his later poetry, as well as, and most obviously, his non-fiction.

The circumstances of its delayed completion made A Novel of London a work of historical rather than contemporary fiction even as it first appeared. In its epic sweep, it is more similar to Crnjanski's earlier lengthy novel Migrations (1929-1962), which is set in the eighteenth century, than to his quintessentially modernist fictional debut The Journal of Čarnojević (1921) which proceeds by association and eschews clear plot development, while reading like Joyce or Woolf, avant la lettre.

Although less experimental than The Journal, A Novel is just as modern in its thematic preoccupations. It is, as its title suggests, primarily a portrait of a city, a cosmopolitan, post-imperial metropolis. Crnjanski's teeming, alienated megapolis is more akin to T.S. Eliot's London in The Waste Land (1922) than to the depictions of the city by any other writer with which I am familiar.

T.S. Eliot famously draws upon Dante: that moment in the third Canto of the Inferno when the renaissance poet reaches the underworld. The sign above hell's gates reads, famously, "Abandon all hope ye who enter here". Beyond it, Dante hears the lamentations of the multitudes unable to escape the eternity of suffering. He observes: "And I, who was gazing, saw a banner, that whirling ran so swiftly that it seemed to me to scorn all repose, and behind it came so long a train of folk, that I could never have believed death had undone so many." (Dante 1920: 17)

In "The Burial of the Dead", the first part of The Waste Land, T.S. Eliot offers a corresponding vision of workers flooding across the Thames into the City of London. He paraphrases Dante: 
Unreal City,

Under the brown fog of a winter dawn,

A crowd flowed over London Bridge, so many,

I had not thought death had undone so many.

Sighs, short and infrequent, were exhaled,

And each man fixed his eyes before his feet.

Flowed up the hill and down King William Street,

To where Saint Mary Woolnoth kept the hours

With a dead sound on the final stroke of nine. (Eliot 1954: 53)

The Waste Land's anguished Dantean voice rising as an intermittent solo amid the cacophony of humanity - an exhausted, half-dead mass of people - is not only the key voice of poetic modernism but also the quintessential sound of a war's aftermath. In Eliot's case the war in question is the Great War of 1914-18: he offers references to demobbed soldiers, allusions to the trenches ("rats' alley where the dead men lost their bones") and shell shock. Crnjanski, of course, depicts the aftermath of World War Two, but his London represents a similar hellish vision:

The passers-by, however, pass him by as though in some kind of a mirror which multiplies him too. He has become one of those mute passers-by, looking at no one and speaking to no one. They pass by like a river. The Styx. A river of workers, male and female, of office clerks, apprentices, sales assistants, step sweepers, and all this flows by, it seems to him, inaudibly, through him, not around him. And this river is composed of a multitude of faces, noses, eyes, hats, heads, legs, all dispersing, scattering, falling apart. (Crnjanski 1971: 127, my translation)

Among the displaced masses in The Waste Land, there are many foreigners. One of them, Marie, inspired by the Austrian Countess Marie Larisch, opens Eliot's poem with an extensive recollection of a European world erased by the war. Marie remembers her stay "at the arch-duke": she is referring to Crown Prince Rudolf, whose successor, Ferdinand, was assassinated at Sarajevo. She belongs to the same prelapsarian, feudal, aristocratic Europe from which the Repnins had been expelled into the inferno that is the British capital:

Summer surprised us, coming over the Starnbergersee

With a shower of rain; we stopped in the colonnade,

And went on in sunlight, into the Hofgarten,

And drank coffee, and talked for an hour. 
Bin gar keine Russin, stamm' aus Litauen, echt deutsch.

And when we were children, staying at the arch-duke's,

My cousin's, he took me out on a sled,

And I was frightened. He said, Marie,

Marie, hold on tight. And down we went.

In the mountains, there you feel free.

I read, much of the night, and go south in winter. (Eliot 1954: 51)

I am not sure if Eliot's influence on Crnjanski is conscious, or if the similarity is a coincidental product of shared experience and a generational world view (T.S. Eliot was only five years older than Crnjanski and they were both traditionalist in their outlook and modernist in their literature), but the parallels in the polyphonic orchestration of these works are striking.

Further similarities with Eliot are discernible in Crnjanski's long poem The Lament over Belgrade which he wrote in his British exile in 1956 and which was read at his snow-bound funeral in Belgrade in December 1977. The poem consists of two strands, woven in counterpoint. Odd stanzas offer a cacophony of painful personal memories punctuated by multilingual whispers and cries similar to the voices haunting The Waste Land and The Four Quartets. Even stanzas address Belgrade directly, and accumulate to offer an ethereal, elysian vision of the Serbian and then Yugoslav capital. If London is hell for Crnjanski, Belgrade is heaven.

With its complex sound repetitions and its elegant rhyming schemes, The Lament has resisted every attempt at translation into English hitherto. Even its title can so easily be misunderstood. The Lament is in fact a paean to Belgrade, an ode to the city written at the time when its poet could not reasonably have hoped to return to it. Crnjanski wrote it while on holiday on Cooden Beach, a dull stretch of the suburbanised Southern English coast between Eastbourne and Bexhill. I can't imagine a more mundane location for the birth of one of the century's greatest poems in any language. Although Crnjanski places Repnin's final scene in A Novel of London in Folkestone, Cooden Beach would have been a perfect setting for the moment when his hero walks into the sea with stones in his pockets, never to be seen again. In 1941, and not far inland from this stretch of coast, Virginia Woolf walked into the Ouse, she too with stones in her pockets. It was a suicide Crnjanski might well have been aware of when he composed the ending of his novel.

I love the sea, and Britain's beaches can be as beautiful as any in Europe, but I usually find this particular stretch of the English Channel rather depressing. It is where old people have long gone to await their final hour in countless residential homes or rows of low bungalows overlooking the sea through marram grass. The water is almost 
always grey and the sound of waves endlessly falling on shingle makes one understand why the poet Matthew Arnold chose to reflect on the "melancholy, long withdrawing roar" of Christian faith during his honeymoon, a meditation which produced his majestic and melancholy "Dover Beach" (1867). If Crnjanski had been suicidal in London, he was ill advised to holiday on Cooden Beach.

Some months ago, I went for a hike on the South Downs in order to visit some of the locations associated with Virginia Woolf and her circle. There are so many in that part of Sussex that it is sometimes called Bloomsbury by the Sea. The Downs offer a glorious chalk escarpment from which to view Southern England and the Channel. On a clear day you can see almost as far south as France and, in the opposite direction, you imagine London in the dark lines on the north eastern corner of the horizon. I kept thinking how often, in London, I forgot that I lived on an island, and then, how close that island was to continental Europe. The day was sunny and the Channel was, for once, sparkling when I spotted Cooden Beach.

Crnjanski's famous black and white photograph on Cooden Beach flashed before my eyes. In it, he stands alone against miles of pebbles and waves. The image is cropped so that you cannot see if he is standing or resting against something. It is also doubly incongruous. First, Crnjanski is smiling, and he doesn't often do that in the pictures taken in England. The smile doesn't seem forced: it suggests that I might be wrong about the choice of destination for that particular break. Second, he is wearing a dark suit with a white pocket square, and looks, even by mid-twentieth century standards, a touch too formal for a day by the sea. He reminds me again of T.S. Eliot, "the most bank clerky of all bank clerks" according to Aldous Huxley, and of Virginia Woolf's snide remark in a letter to her brother in law: "Come to lunch. Eliot will be there in a four-piece suit". (Davis 2016) But then I also remembered the Yugoslav ambassador Srdjan Prica writing how, on his way from London to Belgrade, Crnjanski wore his English tweeds when he reached the Adriatic coast to stay at Prica's house in Opatija. Too formal, indeed, and far too warm for high summer, but he had no other clothes.

I wondered if Crnjanski knew, while he lingered on that pebbly shore composing The Lament, about all the little English churches hidden in the Weald to the north behind him. They are as beautiful as the monasteries of his beloved Fruška Gora, and, like Fruška, they are now - although not in Crnjanski's time - increasingly surrounded by acres of undulating vineyards. If its monasteries are sometimes described as the soul of Serbia, then such parish churches are the soul of England. In the Weald, a number of them are painted inside, like Serbian monasteries, some with ancient frescoes which survived the Reformation, some with more recent wall paintings by one of the many artists who chose to live in this secluded part of the world. I wondered if Crnjanski knew what he was missing while missing Belgrade. 


\section{References}

Alighieri, D. (1920). The Divine Comedy, trans. by Charles Eliot Norton. Boston: Houghton Mifflin. Volume One: Inferno.

Arnold, M. (1867). Dover Beach. In: New Poems, Boston: Ticknor and Fields, 95.

Bunjac, V. (ed.) (1982). Dnevnik o Crnjanskom. Belgrade: BIGZ.

Crnjanski, M. (1921). Dnevnik o Čarnojeviću. Belgrade: Sveslovenska knjižarnica M. J. Stefanovića i druga.

Crnjanski, M. (1962). Seobe i Druga knjiga Seoba. Belgrade: Srpska književna zadruga. [English translation: Milos Tsernianski, Migrations, trans. by Michael Henry Heim. Boston: Houghton Mifflin, 1994.]

Crnjanski, M. (1962). Lament nad Beogradom. Johannesburg: Garamond.

Crnjanski, M. (1971). Roman o Londonu. Belgrade: Nolit.

Crnjanski, M. (1992). Ispunio sam svoju sudbinu, edited by Zoran Avramović; afterword Nikola Milošević. Belgrade: BIGZ.

Davis, G. (2016). What to Make of T.S. Eliot?. Humanities: The Magazine of the National Endowment for the Humanities, Fall 2016, 37, 4. <https://www.neh. gov/humanities/2016/fall/feature/what-make-t-s-eliot>.

Eliot, T. S. (1954). The Waste Land, Selected Poems. London: Faber and Faber (First published in 1922).

Eliot, T. S. (1954). The Four Quartets, Selected Poems. London: Faber and Faber (First published in 1941).

Goldsworthy, V. (2015). Chernobyl Strawberries: A Memoir. Tenth Anniversary Edition. London: Wilmington Square Books (First published by Atlantic Press in 2005).

Goldsworthy, V. (2015). Gorsky: A Novel. London: Chatto \& Windus.

Goldsworthy, V. (1998). Inventing Ruritania: The Imperialism of the Imagination. New Haven and London: Yale University Press.

Goldsworthy, V. (2018). Monsieur Ka. A Novel. London: Chatto \& Windus.

Popović, R. (2008). Akademija? Ne hvala. Novosti, Belgrade, 19 February 2008. (25 October 2019) <http://www.novosti.rs/dodatni_sadrzaj/clanci.119. html:278902-Akademija---ne-hvala>.

Snel, G. (2009). Milos Crnjanski in Exile. In: J. Neubauer and B. Z. Török (eds.), The Exile and Return of Writers from East-Central Europe: A Compendium, Berlin and New York: Walter de Gruyter, 309-324.

Vapnyar, L. (2018). Happy Families: Lara Vapnyar on Vesna Goldsworthy's Adaptation of Tolstoy in Monsieur Ka. Los Angeles Review of Books. (25 October 2019) $<$ https://lareviewofbooks.org/article/happy-families-lara-vapnyar-on-vesnagoldsworthys-adaptation-of-tolstoy-in-monsieur-ka/>. 